\title{
ONTOLOGY AND GNOSEOLOGY OF CAPITALISM IN ISAAK ILLICH RUBIN: "ESSAYS ON MARXIST THEORY OF VALUE"
}

\author{
Santiago Javier Armesilla Conde ${ }^{1}$ \\ Universidad Complutense de Madrid
}

http://dx.doi.org/10.5209/rev_NOMA.2013.v39.n3.48325

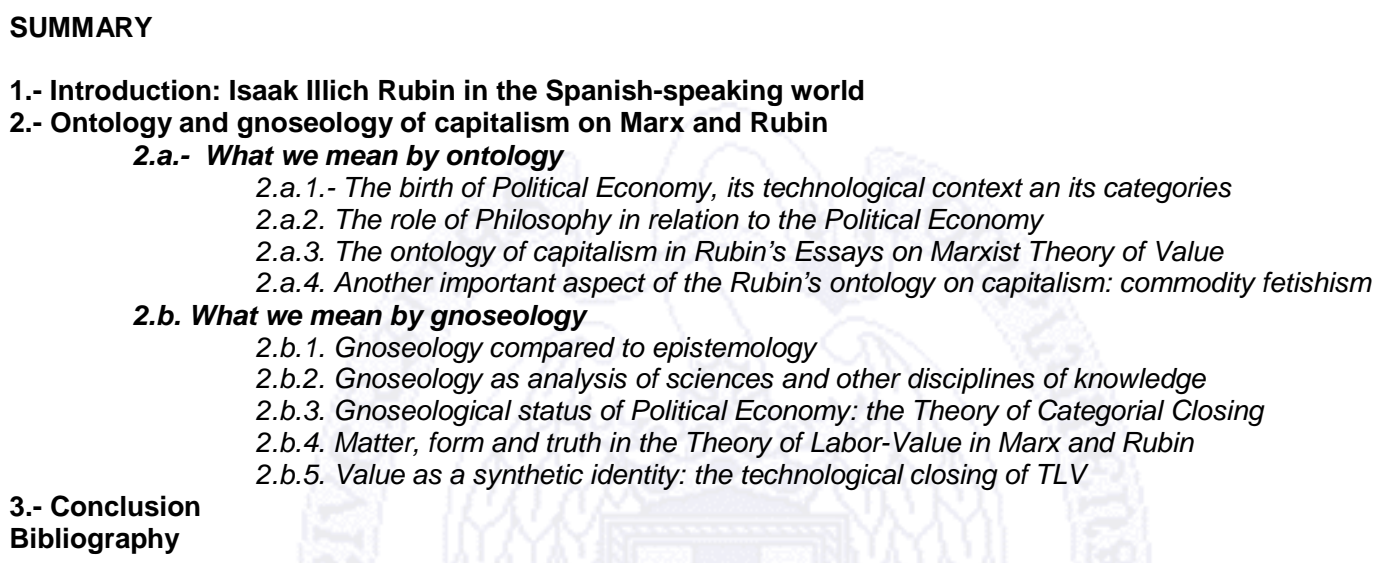

Abstract.- This concise essay attempts to show why Isaak Illich Rubin is, until today, the best interpreter, commentator and developer of The Capital of Karl Marx, understanding Marx's work as an ontology and a gnoseology of the capitalist economic system. To do this, we analyze the relations existing between Marx, Rubin and the theory of science of the Spanish Marxist philosopher Gustavo Bueno. In this way, we can interpret the work "Essays on Marxist theory of value" also as an ontology and a gnoseology of capitalism.

Keywords.- Rubin, capitalism, theory of labor-value, Marx, Politic Economy, Marginal Utility, ontology, gnoseology, science, technology, technique, scientific truth, Gustavo Bueno, Theory of Categorial Closing, circularism, socialism, Philosophical Materialism.

\section{1.- Introduction: Isaak Illich Rubin in the Spanish-speaking world}

Russian Isaak Illich Rubin (June, $12^{\text {th }}$ of 1886 - November, $25^{\text {th }}$ of 1937 ) is, for some authors, the best and, at the same time, the most unknown of the Marxist

$1 \quad$ Bachelor degree in Political Science and of the Administration at Universidad Complutense de Madrid, Spain. PhD student in Applied Economics. PDI \& Honorary collaborator of the Department of Applied Economics $\vee$ at Universidad Complutense de Madrid. 
economist of the $20^{\text {th }}$ century. His tragic life (disappeared during the soviet Great Purge of 1937), bequeathed us a short but wonderful academic production. He is considered to be the most important developer of the Marxist Theory of Labor-Value of his time. He is the author of five books (among some articles and other writings): History of Economic Thought; Contemporary Economics in the West; Classics of Political Economy from the Seventeenth to the Mid-Nineteenth Century; The Marxian Theory of Production and Consume (not translated in English); and Essays on Marxist Theory of Value (third edition of 1928, by Gosudarstvennoe Izdatel'stvo, Moscow-Leningrad). As of today, two of them were translated to English, A History of Economic Thought and the Essays on Marxist Theory of Value.

In the Spanish-speaking world, only two books of Rubin were translated. Essays on Marxist Theory of Value was translated (as Ensayos sobre la Teoría Marxista del Valor), by Néstor Miguez, directed by José Aricó, founder of the Argentinean Marxist magazine Pasado y Presente (1963-1965). In September of 1974, Pasado y Presente, as an editorial, published Ensayos sobre la Teoría Marxista del Valor in Córdoba, Argentina, and were distributed by Siglo XXI Editores S.A. in Argentina in the 1970's (were re-edited in Mexico in 1977). Twenty seven years later, in march of 2011, the first volume of his History of Economic Thought ("The mercantilists"), is translated to Spanish by Marxist economist and professor Diego Guerrero (Historia del Pensamiento Económico: Volumen 1, Los Mercantilistas, Maia Ediciones, Madrid 2011). Guerrero plans to translate the remaining volumes of this book. With Guerrero, other Spanish economista such as Xavier Arrizabalo (the both of them, Political Economy professors at the Applied Economics $V$ Department, on the Faculty of Political Science and Sociology of the Universidad Complutense de Madrid) are working now with Rubin's writings in order to implement new directions in the Marxist economics in Spain. In other Hispanic countries, such as Argentina, Rolando Astarita is one of the most important Marxist economist developing some ideas that Rubin studied in his economic works. But Rubin's legacy is not only high in Political Economy in the Spanish-speaking world. In Sociology, Spanish Juan Miguel Valdera from the University of Granada is developing interesting investigations about the social relations between classes and institutions in the Soviet Union, following some Rubin ideas (Valdera also speaks English and Russian).

There is no doubt that in many cases, in order to study the theoretical contributions of a person, it is necessary that those studying the theories of that someone must have to do it in their mother tongue, for a greater and easier expansion and understanding of his ideas. But international cooperation in the academic field is necessary to achieve this, and especially in the case of Rubin's legacy, an author so little known outside of Russia, and even in Russia itself. Therefore, the Spanish translation of the works of Isaak Illich Rubin, not only in Spain but also in other Hispanic nations, necessarily requires international cooperation with the Russian academy and with other countries, including the Anglo-Saxon world (or some European countries like Germany), in which the knowledge of the Rubin's legacy has more tradition.

At the moment, the translated works, specially "Essays on Marxist Theory of Value" (the most important, and most translated, work of Isaak Illich Rubin), serve as a very solid basis in the Hispanic world for analysis, not only on 
economics, but also on the technological and philosophical fields, following very interesting ways, linking the legacy of Rubin with the theoretical developments of the Hispanic Marxist tradition. Ways that can be expanded if Rubin's works could be translated into Spanish, working with international colleagues to publicize the legacy of this soviet economist, being this, without a doubt, the best tribute we can offer to him.

\section{2.- Ontology and gnoseology of capitalism on Marx and Rubin}

\section{2.a.- What we mean by ontology}

\section{2.a.1.- The birth of Political Economy, its technological context an its categories.}

To perform a coherent development of what we are trying to expose, we noted that, in order to understand the importance of what we attach to the work of Rubin, our statement of the question will follow a scholastic methodology, that is to say: definition of prior concepts, development of the question and a final conclusion.

As we have already said, in this article we are trying to show why the work of Rubin (and therefore, The Capital of Marx) is an ontology and a gnoseology of the capitalist economic system. To do this, we must define what we understand by ontology and gnoseology. It is necessary a solid framework to demarcate this matter, because only then, in our view, can be settled the theoretical and scientific importance of Rubin's development of Theory of Labor-Value (TLV from now). Knowing beforehand that Rubin was an economist, we are not trying to frame his academic work outside of Political Economy and within Philosophy and/or Theory of Science. We are not trying to disturb any economist, encouraging intrusionism between disciplines, sometimes inevitable, but for many an intolerable challenge, many times with reason. But the importance of Marx's economic works, and here there, without doubt, also enters the developments of the same as that carried out Isaak Illich Rubin, overruns the economic field. A field continuously crossed by elements of other diverse fields (technological, scientific, political and philosophical fields, also psychological). Our gnoseological approach on Political Economy makes us see this is not a "closed science", as it is any of the so-called Natural Sciences or Formal Sciences (Mathematics, Geometry, etc.). But, like the rest of the so-called "Human Sciences" (Mathematics and Physics as, as far as we know, developed by rationally and socially organized human beings too), it is a discipline not closed, woven and influenced by other Natural and Human or Social Sciences. Later we will explain what we mean by gnoseology. For now, we will bring it is inevitable that the Political Economy field is not closed, while there are slots within this discipline whose gnoseological truth is greater than in others. And the importance of Rubin in this aspect is fundamental.

In addition, Philosophy and Political Economy (among other disciplines) constantly suffer a reciprocal influence. Not only because some of the most important economists of History were also philosophers (Adam Smith, Marx, Jevons, etc.). But because the ontological approach of the reality that these 
philosophers were following, necessarily affected the gnoseological developments of their economic theories. The case of Marx is clear, because of the influence of Hegelian dialectics in The Capital. In Jevons, for example, cannot be understood his theory of Marginal Utility without the influence of Bentham. This is essential, because we do not say that Philosophy, specially Philosophy of Science (gnoseology), have to interfere Political Economy and vice versa, nor that they are the same (and this relation is similar between Philosophy and other disciplines of knowledge, are scientific or not). What we are saying is that sciences do not come from Philosophy, but necessarily from the technologies. At the same time, that give rise to the development of new technologies (the scientific and technical revolutions). For example, Geometry comes from the technologies of surveyors and bricklayers. Chemistry comes from technologies of metalworkers or dry cleaners. Perhaps it could be said that Philosophy of our tradition (the Hellenic tradition), unlike the philosophies of different traditions (India, China) is largely molded by Geometry, because, in fact, it pretends to be a "geometry of ideas" (ideas that cross categories and open up ways through them). That the "first philosophers", such as Plato, Anaxagoras, Pythagoras, etc., were great geometricians, does not have to mean the Geometry outbreak of Philosophy but rather the reciprocal. And properly, we would say no vice versa. So Philosophy and sciences have different sources, but these sources call to converge (sometimes with turbulences), and when they converge they amend mutually.

Political Economy is not properly a science, and it does not have and only technological origin. Political Economy emerges as a discipline in the $17^{\text {th }}$ Century, at the same time of the Metaphysics of Descartes, Malebranche and Leibniz. Through a process we call "theological reversal", this Metaphysics turns, in part, to Mechanics and, also, to Political Economy.

In the constitution of various particular sciences, and of the categorial specialties linked to the written language (Astronomy, Geometry, etc.), was essential the differentiation process between classes of professional specialists, such as craftsmen, engineers, specialists in religion and others. This differentiation process was developed at the same time of the process of division in social classes. This made very complicated the connection between this process, but without getting confused both. These events were culminated in the Modern Age, in the beginning of the constitution of various sciences and other disciplines of knowledge.

This historical origin has permitted the emergence and conformation of a plurality of particular sciences, relatively autonomous of each other, which allow to establish categorial relations which are not only grammatical. And the effective plurality of particular sciences serves as the basis of restoring ontological categories for each science and for each particular discipline, including Political Economy.

At the time that a new scientific unit is constituted, it is when produces the process we call "categorial closing". This is an historical, institutional, sociological, anthropological and, on the other hand, also logical-material and gnoseological. We explain this better when we define what we mean by gnoseology. But at this point, we have to say all sciences comes from differentiated craft trades. So the scientific categories are developed based on 
an own professional tradition. So, in the case of Political Economy, apart from some professional philosophers (Plato, Aristotle, Saint Thomas, De Oresme, Hume, Adam Smith, Stuart Mill, Marx or Jevons), and despite of the pioneers William Petty and Quesnay, and the academic institution of Political Economy by Alfred Marshall, if we perforate the philosophical veil of Political Economy origins, we can find in its conformation a technological origin, developed in parallel, but not after, the interpretations on the economic activities of societies that have done some philosophers. Schumpeter, in his History of Economic Analysis, affirms that Political Economy could not confirm nor develop apart from a living tradition of bankers, accountants, merchants, amanuenses, State regents or amateurs of its study. Gradually, they were closing Political Economy in a categorial way, if not entirely, at least partial regions of its own field. These adhesions, at certain times, have acted as locking mechanisms of the economic Reason in a categorial sense. But, however, at the same time, these adhesions make possible the cut between these and the economic categories themselves.

So the academic economic Reason, of theoreticians of Political Economy, has a close connection, therefore, with what might be called "mundane" economic Reason, that of those that, for example, deposit their money in a bank, of those who invest a capital on the stock exchange or in a company, or those who operate with means of production to produce goods. The relations between academic and mundane economic Reasons are the base of the Political Economy field. And the both are a product of the relations of production. It is important to say that we mean by economic Reason the feature of what has been built operatively (by means of compositions or separations). Also, this feature possesses an identifiable and reproducible structure in a biological or social context. This Reason (academic and "mundane") exist, like all other scientific and technological reasons, as a historical development of the relations of production. This does not mean that Political Economy is the "mother of all sciences". We only affirm that modern categorial sciences and other disciplines are historical creations institutionalised and developed through the development of the relations of production in the capitalist economic system (and in the Real Socialism of the Soviet Empire).

\section{2.a.2. The role of Philosophy in relation to the Political Economy}

The relations of productions are, in Rubin's Essays on Marxist Theory of Value, the key of the Marxist analysis of capitalism. For Rubin, Marx's Historical Materialism (as his philosophic system about History, political societies, classes and economic systems) and his TLV revolve around a basic problem: the relations between the productive forces and relations of production. So the principal matter of both is the same: the changes in the relations of production depending on the development of productive forces. And if Political Economy, for Rubin, is essentially the study of a defined socioeconomic formation (capitalism), the critique of Political Economy in Marx is, first of all, a philosophical critique of this discipline at the moment Marx wrote The Capital. This critique, followed by Rubin in his Essays..., shows Marxian economics in the Marx-Rubin way, as a critic reclassification of the categories of economic field. This reclassification is, essentially, an ontological reclassification of this categories. So, if this reclassification is related to what is already there (the 
capitalist economic system), this critic reclassification is absolutely ontological because ontology is the part of the Philosophy relates to what is already there. If ontology is the study of the nature of the being, the existence and the reality, the Marx and Rubin's ontology of capitalism is not only the economic study of this economic system, but also the philosophical study of the nature of the being, existence and reality of capitalism. This allows us now to define the role of Philosophy in the whole of the know, in general, and in relation to Political Economy in particular.

To define this role, we will take the definition of Philosophy of the Spanish Marxist philosopher Gustavo Bueno, creator of a heterodox Marxist system called by himself Philosophical Materialism (on his book El Papel de la Filosofía en el Conjunto del Saber, Editorial Ciencia Nueva, Madrid 1970).

For Bueno, philosophical knowledge is not a doxographic knowledge, nor a past tense knowledge, about works of Plato, Aristotle, Spinoza or Hegel. Philosophy is a knowledge about the present and for the present. Philosophy, in Gustavo Bueno terms, is a "second degree knowledge", which therefore presupposes other previous "first degree knowledge", such as technical knowledge, mathematical, political, biological, economical, etc. Philosophy, in its strict sense, is not "the mother of sciences"; Philosophy presupposes a sufficiently mature state of science and technology that can begin to set up Philosophy as a defined discipline. For this reason, Philosophy deal with ideas gush forth precisely from the confrontation of the most diverse technical, political, economic and/or scientific concepts, from a certain degree of development. These concepts are more abundant as it occurs that development.

As a "second degree knowledge", Philosophy cannot be assigned to a closed categorial field, such as Physics or Mathematics. Because the "Philosophy field" is in function of others, of their analogies or of their contradictions. The identifiable lines shaped by the analogies and contradictions between the sciences and other cultural contents, are called ideas by Gustavo Bueno. These, in a scientific and technological sense, show us Philosophy no longer as an activity oriented to contemplate a different world from the conceptualized real world. In our present, in all its parts, is conceptualized by the technical and by science, because there are no truly "virgin lands" of concepts. To let go of the ideas from the concepts, Philosophy cannot engender ideas that do not stem from categorial or technological concepts. But Philosophy is necessary to make ideas light of the concepts, because concepts are "fraught with ideas". By this way, we avoid the utopian formulas purporting to define Philosophy trough pompous psychological concepts, such as "Philosophy is the love for knowledge", or "Philosophy is the research of the first causes", or "Philosophy is the approach of the questions of existence". Instead, we say: Philosophy is the confrontation with the ideas and with the systematic relations between the ideas. But without the need to assume that the ideas constitute an organized and compact world. The ideas are of very different ranges, appear in different levels in time; nor are relieved entirely, or intertwined all. The idea of God is not an eternal idea, it appears in a date more or less determined in History. Ideas like progress and culture are not eternal ideas: are modern ideas, with no more than a couple of years of life. Its pace of transformation use to be slower than the pace of transformation of scientific, economic, political or cultural realities of those that had emerged; but it is not necessary to substantiate it. 
Therefore, Philosophy does not have a content likely to be exploited or discovered by itself and in itself, not even to be "created". Philosophy exist in function of the realities of its present, is a "second degree" activity, and therefore the search for an "authentic philosophy", as if it could be found in any particular place. The process Gustavo Bueno called Philosophy is, for example, when we have found with the contradiction between a law of Physics and a Mathematical law. When this occurs, we must say: "I do not look for Philosophy, but I have had to face the contradictions between ideas and situations. And, from here, what I'm looking for are the mechanisms under which have been produced that contradiction, their analogies with others, etc.".

So, we have just defined what we understand for Philosophy and his role of the know in general. In particular, with Political Economy and other "social sciences", the role is the same from an ontological point of view. Because of this, Marx and Rubin determine in his works that a critique of the Political Economy, from the basis of Historical Materialism, must have to face the contradictions between the ideas that economists had about the economy and the real situations of the capitalist economic system. Marx, and Rubin, had determined, not only following the methods of Political Economy, but also the methods of Philosophy (ontology and gnoseology), some of the contradictions between ideas and situations in the capitalist economic system, the mechanisms under this contradictions has been produced and their analogies with others. Therefore, in this sense, works like The Capital and Essays on Marxist Theory of Value are also philosophical works, are ontology and gnoseology of capitalism.

\section{2.a.3. The ontology of capitalism in Rubin's Essays on Marxist Theory of Value}

In spite of a certain metaphysic substantialism, criticized by Kant, ontology is an essential part of Philosophy. Philosophical Materialism has its own ontology, far from metaphysics or idealistic assumptions. We are not going to give in this article a full description of materialist ontology. But to show this ontology is interesting in order to analyze Rubin's TLV theories, we must say that the ontology of Philosophical Materialism is divided in two levels that should not be confused: the level called "general-ontological matter", which deals with the Be, the reality as itself (including the parts of reality we don't know until now and even the parts of reality we will never know); and the level called "specialontological matter", which studies contents given to scale of operational (Praxis) consciousness and conform the World we know as an ontological reality. Part of this ontological reality is the capitalist economic system. And Rubin, following Marx, develop on his Essays... a study of this system at a scale of operational conciousness that help to conform our economic and social world. Not in vain, for Rubin -and for Hilferding too-, Historical Materialism and TLV have the same starting point, i.e., Labor as a core element of human society (labor is done in scale of operational consciousness and help to conform the World we know as an ontological reality). The development of institutionalized and rationalized labor in political societies finally determines the entire development of these societies.

The labor activity of the people is in a constant change, sometimes faster and sometimes slower, and according to the historical moment its character will be 
different. For Rubin, this process of change and development of labor activities involves changes in two types: in the first place, changes in the means of production and the technical methods by which men act on nature, i.e., Changes in the productive forces of political societies; secondly, in correspondence with these changes, there are others also on the structure of the relations of production between individuals, between the participants in the social process of production. The economic formations, or kinds of economic systems, differ in the nature of the relations of production between people. The theoretical Political Economy research about a defined socioeconomic formation, specifically of the commercial capitalist economy.

The capitalist economic system represents the union of the technical-material process and its social forms, i.e., all of the relations of production among people. The specific activities of the people in the technical-material production process presupposes relations of production between them, and vice versa. In the end -and this is the basis of Rubin's work as an ontology of capitalism- the ultimate goal of Political Economy is to understand capitalism as a whole, as a specific system of productive forces and relations of production among people. But to deal with this ultimate objective, Political Economy must distinguish first and foremost, through abstraction, two different aspects of the capitalist economic system: the technical and technological aspect and the socioeconomic aspect, the technical-material process of production and its socialhistorical form, the material productive forces and the social relations of production. Each one of these two aspects of the economic process is subject to a distinct science. The study of social engineering, even in an embryonic stage, should convert the productive forces of society in its interaction with the relations of production as its object of analysis. On the other hand, the theoretical Political Economy deals with the specific relations of production of the capitalist economy in its interaction with the productive forces of society. Each of these two, which only deals with an aspect of the whole production process, requires the presence of the other in the form of a course that underlies Political Economy investigation. Although Political Economy deal about the relations of production, always presupposes its unbreakable link with the technical-material production process, and this involves a stage and a specific process of exchange of productive material forces.

For Rubin, it is necessary to understand that the phenomena treated in The Capital are own in a specific economic system, if we want to understand that book. So, for him, the adjustment of the relations of production in the productive forces -a process that takes the form of the growing contradictions between the relations of production and productive forces, and the form of social upheaval caused by these contradictions- is the basic issue of the theory of Historical Materialism. So the Marxist method of analysis can be summed up as it follows: a) analysis of the relations of production in capitalist societies; b) process of changes caused by the evolution of productive forces; c) emergence of contradictions usually expressed in crisis. This economic though is, also, pure ontology of capitalism.

The technical-material aspect of the capitalist production process is not what is being discussed in Political Economy, but its social form, the totality of the relations of production that constitute the economic structure of capitalism. The productive technical and technology (productive forces) is included in the 
economic theory of Marx only as a course, as a starting point taken into consideration to the extent necessary for the explanation of the genuine object of analysis: the relations of production. However, we must now clarified one essential ontological aspect of the TLV of Rubin. It is true that the distinction between the material process and the technical support for the production and its social forms is essential in Marx, according to Rubin, and this helps to define Political Economy as a "social and historical science". The technical-material process would be the basis on which develops the relations of production. It is for Rubin the key that allows understanding of economic systems and the ontological theory of Marx about capitalism. Because of this technological base, political societies produce the necessary relations between men. But the technical-technological base and its social forms, as base and superstructure respectively, are not watertight compartments. Need each other to function, as the tree needs the roots (base) and the leaves (superstructure, which collects water from the rain, the air and the light of the sun), because without leaves, the tree dies. Thus, the capitalist economic system could not exist without its material and technical base. But this would not be the same without the social ways that allows it to develop. And this ontological idea is essential to understand capitalism, and any other complex economic system, as a temporary historical social form, as well as the goods capitalism allows to produce.

Gustavo Bueno understands, from the coordinates of his Philosophical Materialism, that base and superstructure are conjugated concepts. This idea allows us to understand the ontology of Rubin (and of Marx) in a very clear way. Conjugated concepts is an expression that is used to refer to a set of pairs of concepts whose oppositions between the terms of each pair are not reduced to the classic competitions of contradictoriness, setback or correlation. This conjugated concepts are those pairs of concepts whose terms (A/B) supports the dilemma of the complete system of connection of diagrams, called by Bueno "metameric" and "diameric" connections). The metameric connection diagrams are those considered by the two terms (A and B) as "global". They can be of juxtaposition, reduction, articulation or merger. On the other hand, the diameric connection diagrams are connections of homogeneous parts of $A(a 1, a 2, \ldots$, an) established through $B$, without being reduced to it. Let's say that $B$ has been "infiltrated" between the parts of $A$.

The conjugated concepts are developed in two levels: at the phenomenologicalhistorical level and in the essential level, which constitutes an overcoming of the previous position that validates the connection diagrams. In the first place have the metameric connection diagrams, while in the second are verified the diameric connection diagrams.

An example, in science, of a couple of conjugated concepts is "rest/movement". Until Galileo Galilei, the connection diagrams corresponding to this pair of concepts have been interpreted as metameric: the reduction of the movement to the rest of the eleatic thought, the Aristotelian juxtaposition of immobile and the mobile being, etc. But since Galileo to Einstein, the connection diagram is diameric: the rest is conceived as a particular relation between bodies in motion. 
In the case of the relation between base and superstructure, traditional -and vulgar- Marxism identified the economy with the base (production, distribution and consume), and everything else (such as law, religion, sciences, language, art, philosophy, etc.; definitely, all final products of social relations), would be superstructures. But, really, base is like the bones and superstructure are the remaining tissues of the body of the vertebrates (or the roots and the leaves of the trees, as we said before). Because the bones, the skeleton, sustain the body (such as the base of the superstructure), but the bones were not given prior to the remaining tissues in the body, but springing together with other tissues of the body itself, from its diverse blastodermical leaves. From there could be achieved in the evolution the functions of "columns" that bore the "factory" of the organism. This was like saying that the economic basis of an organized society could not be regarded as a stratum previously developed in which the "surplus" could be transformed into various superstructural morphologies, that could slump into as soon as the base lost its own consistency. But Rubin's conception of capitalism, and following Marx's thoughts, following strictly Historical Materialism, help to see that the basis, with its own morphology, was structured as such from the so-called superstructure that, consequently, should also lose their designation (we could call them "sheath structures").

For example, it was admitted that oil, throughout the $20^{\text {th }}$ century, and in growing, was one of the basic components of our economic system and was at the root of many international conflicts. In particular was implied (by Muslims and Christians) that would have been the oil deposited by "Allah" in the subsoil, being this the basis of the recovery of so many Arab peoples that, until few decades, were included as marginal or underdeveloped people.

The resurgence of Islamic movements, including Islamic Jihad, was supported by the columns of oil wells. On this oil wells, which is owned by certain Muslim countries, rested its resurgent power. However, it is well known (discounting the Koranic theology) that neither the political or economic power in the Arab countries sprang out directly from the oil, because the oil that "Allah" had deposited beneath their territories, lacking any "basic ability" until it had been mined, refined and incorporated into the network of machines and appliances designed to move by explosion engines in cars, airplanes, railways, electric turbines, etc. This is only the segment of a sheath structure, segregated from the All, acquiring the status of a subject of allocation of the global movement. There is no question, therefore, to speak of the economic base as if it were a previous structure and endowed with autonomous dynamism. What was called basis, or even infrastructure (in the terms of Cultural Materialism of Marvin Harris), was always surrounded by other inherited and more complex structures. Neither the arts, not the sciences, nor religions, nor languages, nor the right, were superstructures. And this had already been partially warned in the own course of development of the soviet theory by Isaak Illich Rubin, if we see his Essays... and the rest of his academic work, as an ontology of the capitalist economic system. Apart of a necessary abstraction to allow to distinguish the technical-material productive process from the social relations in capitalism, Rubin's ontology only could be strong and coherent if we see those two aspects as parts of a whole (conjugated concepts). Even the soviet theory of issues in linguistics (Marxism and Problems of Linguistics by Stalin) or 
Marxists economical anthropologists (Godelier), however, prisoners of the base/superstructure dualism, had not another way to collect the not superstructural functions performed by language, art or religion, that reconsidering them as basic features, like Mandeville on his Fable of Bees considered virtues to the flaws.

The concept of superstructure was, perhaps, contaminated from the beginning with the idea of superstition, as the shunt allegedly associated with a waste of energy that could be applied to other higher purposes. This criterion was unreasonable because it would oblige to reclassify the main basic contents in a society like cultural superstructure (regarding "sobriety" of simplicity of Nature).

In this sense Rubin says that Political Economy is not a "science" of the relations between things as the vulgar economists thought, nor the relations between people and things, as stated by the Theory of Marginal Utility, but the relations between the people in the process of production, that is the same as saying that the relations between people through things. Things, goods, produced thanks to a specific particular and historical economic system. Things that are both productive forces (means of production) and means of production, which consolidates even more the base/superstructure relation as conjugated concepts. When we observe the development of the economic categories should always be borne in mind that the subject -the modern capitalist society in Rubin's case- is something given in reality (and in mind, because we know it exist). The categories express, therefore, ways of being, determinations of existence and, often, simple aspects of this subject. Also in the theoretical method of Political Economy is necessary as the subject always be present in representation as well as premise. So, finally, we can say that this circular relations between people through things (through goods that only could be produced in a capitalist economic system and only could circulate on it), is the idea that determines the necessary conjugation between base and superstructure that allows to view TLV of Marx-Rubin as a pure ontology of the capitalist economic system.

\section{2.a.4. Another important aspect of the Rubin's ontology on capitalism: commodity fetishism}

Starting from a particular sociological assumption, that is, the social structure of the economy, Political Economy gives, before all, the features of this social form of economy and the relations of production that are specific to it. Marx, according to Rubin, gives these characteristics in his theory of commodity fetishism, called by Rubin "general theory of the relations of production in the commercial capitalist economy". For Rubin, this theory is the basis of the whole Marxist theoretical economic system, and in particular of his TLV.

Commodity fetishism is a very important aspect of the ontology of capitalism in Marx and in Rubin. Marx saw human relations underlying the relations between things (the relations between people through things), revealing the illusion in human consciousness that originates in a market economy, and its attached to the characteristic things that have their origin in the social relations established by men in the productive process. For Marx, the relations of production and consumption are not relations between things. To think that are relations 
between things is equivalent to give things features born of the relations of production, and this is when commodity fetishism born.

According to Rubin, commodity fetishism theory dissipates from the mind of men the illusion and great deception that originates the appearance of the phenomena in a market economy, and the acceptance of this appearance as the essence of economic phenomena. This appearance is the movement of things, and for the goods and their commercial prices. Actually, this theory reveals that social relations of production inevitably adopt the form of things and may not be expressed but through things. The structure of market economy makes things play a particular and very important social role, by which things acquire particular social properties. Marx discovered, according to Rubin, the objective economic foundations that govern commodity fetishism (Rubin also says commodity fetishism is a "propaedeutics" of Political Economy).

This objective, material, foundations, has an enormous and essential importance to understand the Rubin's Essays... and The Capital of Marx as an ontology of capitalism (plus a gnoseology, that we are going to refer later). Because in the market economy, all the managers and organizers of large and small production, are independent producers of goods. Any particular company is autonomous, its owner is independent, looks after their interests and decides on the type and quantity of goods to produce. On the basis of private property has at its disposal the productive tools and the necessary raw materials to produce, and as the competent legal owner he have the product of his company (the means of production, the goods before its sale and the "surplus value"). The production is administrated directly by separated producers of goods in a microeconomic sense. Not by the society. Society does not directly regulate the labor activity of its members, it does not prescribe what should occur or how much should occur. But the social division of labor unites all the producers of goods in a unified system that receives the name of "national economy", and Political Economy is National Economy, because State is the most important economic variable and category. State administrates production, distribution, property and consumption, even in the most "liberal" of its kind. What Rubin is saying as an axiom is that without a State, there's no relations of production. Without a territory under the control of a State, there's no relations between people through goods. And without the State, commerce is impossible with other political societies, because "national economy" (State) is a "productive organism" whose parts are interrelated and conditioned.

This connection comes from the exchange, with the market (and by the interrelation of markets, of national economies), where good of each individual producers appears in a depersonalized form as separate copies of a particular type of goods, independently of who or where it were produced, or in which specific conditions where it is produced. The goods, the products of the individual producers of goods, are moveable and are evaluated in the market. The connections and actual interactions between individual companies, which we could call autonomous and independent, arise from the comparison of the value of goods and its exchange. On the market, indirectly, societies regulates labor activity for men, because the movement of goods on the market, the rise and the fall in their prices, originate changes in the distribution of labor activity for the separated producers of goods, determines the redistribution of the 
productive forces of the society and causes its entry in certain branches of productions or its departure from those branches.

The interaction and mutual influence of the work activity of the individual producers of goods are carried out exclusively through things, through the products of their labor that appear on the market. How States influence on this matter Rubin show by this example. The expansion of cultivated lands in Argentina or Canada could cause a decrease in Europe's agricultural production only if the prices of agricultural products decrease on the market. Similarly, the expansion of large-scale production ruins to the craftsmen, making them impossible to continue their previous production, carrying them from the countryside to the cities.

So, briefly, in broad outline, the objective-material foundations of the theory of commodity fetishism and, therefore, also of the ontology of capitalism by Marx and Rubin are the following:

a) The technical-material production process at the base and its social form as the superstructure are conjugated concepts that determines any rational and complex economic system, specifically capitalist economic system. But we can distinguish both by a process of abstraction.

b) People in the economic field have relations between them through things, goods produced by people in the same economic field through organized and institutionalized social work, the social division of labor.

c) The social division of labor is developed in the territory of a "national economy", of a state, by individual cells of productions, separated private companies (related each other by the commerce of goods in particular commercial markets, i.e., markets of goods of production). The social division of labor makes possible people are materially related between each other in a national territory. This "dialectic of States" allows international commerce and amplifies social relations between people through things.

d) The direct connection between individual producers of goods is set to the exchange, and this has an indirect effect on its productive activity.

\section{2.b. What we mean by gnoseology}

\section{2.b.1. Gnoseology compared to epistemology}

Once we have shown the materialist ontology of capitalism of Isaak Illich Rubin, already we can define and to deepen its gnoseology, also following the philosophical and economic theoretical work of Karl Marx.

It is important to justify why we choose gnoseology as a term to describe certain processes and events on the economic field referred to by Marx and Rubin instead of epistemology or "theory of knowledge". From the coordinates to Philosophical Materialism of Gustavo Bueno, gnoseology is an opposite term to epistemology and "theory of knowledge". In both its use is not restricted to the relation subject/object of epistemology, purely psychological relation, but it goes to a relation with a third part, the Truth. Therefore, gnoseology doesn't refer to a 
true or false knowledge, but an effective reality, built through operations, as are conceived sciences and other disciplines. Is a theory (or a treaty) of science, from a very particular perspective (logical-material perspective, not psychological, or epistemological, sociological, nor logical-formal or historical). Bueno distinguish two types of gnoseology: general gnoseology and special gnoseology.

General gnoseology is geared toward the determination of a general idea of science to estimate the degree of characteristic scientificity of a specific discipline. Involves two steps:

1) General analytical gnoseology, or analytical: designed to, "anatomical" or structurally, determine the constitutive formal parts of all sciences.

2) General synthetic gnoseology, or synthetic: study the dynamic of "physiological" constitution of science in operation.

Special gnoseology is geared toward the determination of the constitution and the internal limits of a positive specific science ("Gnoseology of arithmetic", "Gnoseology of mechanics", etc.). Cannot be carried forward behind the backs of general gnoseology, nor vice versa.

Philosophical Materialism use the term epistemology, as opposed to the term gnoseology refer to the so-called "theory of true knowledge" (is of a scientific, prescientific, or "mundane" praeterscientific). Its field is organized around the distinction subject/object (cognoscent/known). The field of gnoseology is organized around the distinction matter/form, applied to the sciences.

\section{2.b.2. Gnoseology as analysis of sciences and other disciplines of knowledge}

Firstly, gnoseology here means, of course, the analysis of scientific disciplines, as Geometry, Thermodynamics, etc. By analogy of attribution, gnoseology means the analysis of any other kind of disciplines as well (technological or technical disciplines). Although not all of them are scientific in the sense of the positive sciences. Its organization for teaching oblige to adopt a similar structure to that of the positive sciences. In the Aristotelian tradition of the Posterior Analytics are known as sciences. Therefore, we distinguish the term gnoseology of the term epistemology, reserving the latter for everything has to do with the analysis of knowledge (for example, in the sense of the "genetic epistemology" of Piaget), whether or not organized in the form of a "discipline".

A discipline is inseparable, of course, of the matter around it deals. Musicology is inseparable from the matter constituted by symphonies, sonatas, operas, etc. Ethnology is inseparable from the field formed by the pre-state societies (Amazonian or Australian tribes, for example). However, disciplines are separable from their respective areas, but no more than by the possibility of comparing them with each other, in accordance with similar or counterparts terms, relations or operations (homologies or analogies that are taking place more in the gnoseological syntax background of pragmatic in the ontological level). It is precisely the duality between gnoseology and ontology have to do with the dissociability of the inseparable -we use the concept in a similar sense to the one in Projective Geometry (for example, the duality between points - 
such an intersection of infinite straight- and straight -as a co-alienation of infinite points-) -. We cannot separate the gnoseological from the ontological moment of a science, but we can dissociate the gnoseological perspective from one's own ontological. When we do this, we encounter with the "body of the discipline" in question first, and second we encounter with the matter of the discipline, with the ontological reality itself.

In a gnoseological sense, a discipline consists, in effect, first and foremost, whatever their matter is, in a set of technical and/or social institutions, such as books, professorships, departments, congresses, professional associations of specialists with their correspondent traditions, etc. And this, whether it is the Mariology or Thermodynamics. There are magazines and international congresses of Mariology, in that confront miscellaneous schools, as like of Thermodynamics. The analysis that Hans Kuhn made famous around the paradigms and the scientific communities have to be regarded as referring also to the disciplines in general, whether or not scientific. Not only is there "paradigms" and "paradigm changes" in Thermodynamics, but also in Mariology. So the theory of paradigms of Kuhn is, first, a "theory of disciplines" than only a "theory of sciences".

This creates a great confusion that threatens who speaks of "scientific communities" because, according to what was said, both communities Mariologists and Thermodynamicists- maintained, from a structural, social and historical point of view, mutual and extraordinary similarities, without that these similarities make possible to consider the Mariologists community as a scientific community in a specific sense. We would prefer to speak, for our part, about "disciplinary communities" (including the community of scientists) and not "scientific communities" including the disciplinary. Because, despite of this communities, it is not serious that the sole criterion for defining a successful field of research is to see if a sufficiently large group of scientists (scientists' communities) considered to be of professional interest that field or not, and then, scientific truth is replaced by the consensus.

\section{2.b.3. Gnoseological status of Political Economy: the Theory of Categorial Closing}

In our presentation we propose, to understand the gnoseological status of Political Economy in general, and the gnoseology of capitalism by Marx and Rubin in particular, the gnoseological theory of Philosophical Materialism of Gustavo Bueno as an analytical tool. This gnoseological theory, this theory of sciences in the plural, is called Theory of Categorial Closing (from now TCC). Not to dwell too much, we will deal only the analysis through TCC on the Political Economy, showing as well some particular features of this theory, which after relate them to the gnoseological developments of Isaak Illich Rubin in his Essays....

Gustavo Bueno published in 1972 his own study of Political Economy, entitled "Essay on the categories of Political Economy" (Ensayo sobre las categorías de la Economía Política, La Gaya Ciencia, Barcelona 1972). In this work are already conceived the TCC in one of its first applications. And on this work it was clear the importance of the philosophical study of Political Economy for both delimit the gnoseological status of this discipline, as to go also suggesting 
the anthropological and political implications that are derived from this exercise. After forty years, it imposes -we believe- a critical recovery of the fundamental concepts of Political Economy, such as consumer goods, value, social classes, State, etc. It is necessary to rethink the economic ratio as an inexcusable time for a real philosophical view of political and social events of the present, without detriment to the fact that these terms can overflow Political Economy, and require the intervention of Philosophy.

Not to be forced to deny ontological and gnoseological place of scientific truth exist the TCC. This theory presents a theory of scientific truth as "synthetic identity". The TCC presents us scientific truth, not as the analytical identity that is established between two terms, expressed in an isolated proposition, but rather as a theorem, which now makes not only multiple proposals, but multilayered proposals both syntactic, semantic or pragmatic. The synthetic identities appear as well in the course of categorial closed operations. For a brief description of the notion of operative closing, it suffices to recall, as does this notion in Mathematics or Geometry, being so based on the terms and the relations established between them, we can bring up new terms in the field, such as when in Geometry, from the spin of a triangle in a circle, we get a cone, a new term, without the need for any subject involved in the field.

Now we are going to expose, in a schematic way, the exercise of TCC applied to Political Economy, not as a mere alternative juxtaposed to other philosophies of sciences (nor juxtaposed to economic analysis) that tries to subsume and crush the previous theories, in an attempt to clarify, even minimally, these points of order and distinction of the sciences. This will allow us to expose the congruities between TCC and the gnoseology of capitalism of Marx and Rubin.

Is Political Economy a Science from the perspective of the TCC? And if the answer is yes, what kind of science is?

The terms (variables, constants) of the academic economic language can never become syntactically autonomous, because Political Economy is not a natural science, nor a formal science, but a real science. The terms always refer to the economic reality that is already a language, a product of reason, which by itself can be more or less categorized. Terms like worker, production, market, commodity, "development of the productive forces", etc., already referred to the same radial realities, or circular realities as "social relations of production". On that realistic basis, in which we assumed Political Economy already working, by making reference to a language already, more or less, categorized, we must determine if that economic reason is closing, which would be tantamount to a theory on what is specific about the economic field.

What then is the specificity of Political Economy as a science? When academics study a national economy from the point of view of Political Economy, then starts with the population, the division of this in classes, its distribution in the cities, in the countryside and on the edge of the sea, the different branches of production, importation and exportation, production and annual consumption, prices of goods, etc. It seems appropriate to begin with what is real and concrete, by effective premises. In Political Economy, by the population, which is the basis and subject of all the social process of production. But this is not, as Marx said, the specificity of Political Economy as a science. Is in The Capital, and in Essays on Marxist Theory of Value -among other works-, 
where Marx and Rubin offer an analysis of what they consider the cell, the atom, of Political Economy. Of course, as we said in our ontological definition, there are people linked in the economic field by circular relations, through things, but these relations must be given in a specific way in the economic category. Precisely, the specific way of realizing this circular relation between people, between economic subjects, is mediated by, or combined with, the goods. Although the subjects of the economic field, as modules -because of their works, whether this works were economic goods or not- can be considered as the source and measure of value, it is impossible for them to relate economically if it is not through things. Then we have to be able to introduce the rational economic field as a dialectical concept which includes a reference to the pre-rational, as a field in which the terms appears precisely defined by symmetric, transitive and reflexive relations (circular relations between people through things), as soon as established by the mediation of goods. To maintain its economic limits, is essential, in order to comprehend the gnoseology of capitalism we are arguing, to consider physical goods, because they are objectively "secretable" from modules (from the hands of productive laborers that produce this physical goods and its values).

When on the capitalism part of the variable capital is devoted to the reproduction of the worker, and not -for example- are produced consumer goods for the citizens, the economic system is closing recurrence of work, and at the same time work is thingificated (it implies, in general, the thingification of social relations of production). To a greater or lesser extent, the thingification is always a result of economic closing (it occurs, i.e., when calculating the nutritional needs of a population of workers). Then, the specifity of the economy is based on certain established relations among men mediated by the goods. Relations that are capable to generate new goods (terms) for the economic field.

According to TCC, operating closures of each science (and not its applications to an object in particular) are which determines the unity of each science, its distinction from the rest of the sciences and the distinction between sciences, pseudosciences, ideologies, religions, etc. One of the fundamental requirements for the closing is the segregation of the thematic and historical subject of its field. Taking as parameter the segregation of the operations of the thematic subject (gnoseological subject), and knowing that the operations of the researcher are necessarily present in all disciplines, Gustavo Bueno distinguish between alpha-operative and beta-operative methodologies. In alpha-operative methodologies, the operative subject completely disappears from the field (alpha-1 situation) as in formal and physical-natural sciences. The operative subject partly disappears in situations in which are recognized thematic subjects as operatives. These situations are the so-called alpha-2 situations. In the betaoperative methodologies also observe two times or situations, but here the subject are constitutively part of the field, and are impossible to segregate (trying to build the truths of the sciences in the same scale of operations, which is impossible). The sciences that use beta-operative methodologies are appear to us as anomalous sciences, unable to offer real scientific truths. Two states or situations, as we say, are distinguished according to relations that mediate between the thematic -gnoseological- subject inserted in the field and the operatory subject (the researcher). The beta-1 situation takes place when the 
gnoseological subject is able to reconstruct the operations of the thematic subject (for example, in History). The beta-2 situation presents us a total continuity between the operations of the subjects, closer to the territory of the practices and techniques.

Within the so-called "human sciences" coexist the two types of methodologies we have distinguished (alpha and beta), in such a way that these so irregular disciplines may be simultaneously organized according to these different methodologies, depending if, more or less, it is secreting the operative subjects in their field. As well, Political Economy roamed states alpha-1 as Thermoeconomics; alpha-2 as classical economics, that starting from the operations of the economic agents construct some generic structures of mathematician character, such as functions, curves, etc.; beta-1 as Praxiology; and beta-2 as Economic Policy. That is to say, increased segregation of the gnoseological subject, closer proximity to the alpha-operative state and vice versa. Here takes on its full meaning the idea of the thingification of the subject (module) on the economic field. Because the theory of commodity fetishism also has to do with the thingification of social relations, including the thingification of own subjects, including their labor power. This is another essential question of materialist gnoseology of capitalism, because the thingification is a "result of the closing", which leads us to think that the high closing (alpha states), the greater thingification. The economic agents (the modules) would have to behave not as a human, endowed with "free will", because the specifically human has been the segregated "part" of the subject, but as producers and consumers forced by the spiral of the context.

We cannot conclude this point without the treat about intermediate states in alpha and beta, important for continuing the following point: the alpha and betaoperative I and // states.

Knowing that beta-1 methodologies are characteristics of the scientific disciplines that returning of operations toward structures or determinant essences not overflow the operative territory, but stop in some way of determining what can be formed in the same area, we can distinguish a generic way, and other specific, of this methodologies. In the generic mode (I-beta-1), determinations will be established through objects or technical or technological artifacts, in turn produced by operations (the coincidence of the truth and the fact). In the specific mode (II-beta-1), the determination of operations would be constituted by other operations, that would be the case of the Game Theory, or the psychological disciplines of operant conditioning.

And knowing that in the alpha-1 state, after starting of operations that have given prior constructions, succeed in establishing linkages between terms of the field as if they were offered independently of any operative link (which is what happens in the Formal and Natural sciences), the alpha-2 methodologies do not emanate from connections prior to any operation, but the operation themselves, but progressing to determinate sheath contexts of these same operations, capable of establishing not operative linkages, structures or processes between the terms of the field. The links, structures or certain processes, or are generic to the social and natural fields, and in this case we are talking about I-alpha-2 methodologies, either are specific of social fields, and in this case we are talking 
about II-alpha-2 methodologies. And this point, we repeat, is essential to take up another time to Rubin and his development of the TLV of Marx.

\section{2.b.4. Matter, form and truth in the Theory of Labor-Value in Marx and Rubin}

We have said before that the gnoseology is opposed to the epistemology in both that was on the relation between matter and form at the time to settle the scientific truth. How is the gnoseological relation between the matter, the form and the (scientific) truth in the TLV according to Rubin and following Marx?

We will try to answer this question in a schematic way. As well, we will set the gnoseological basis of TLV (the technical and technological-material production of goods and values and prices associates to it), without delving into other complex developments in Rubin's economic theories, that overflow the pretensions of this article. We summarize the gnoseology of the capitalist economic system according to Marx-Rubin's TLV.

If the ontology of capitalism by Marx and Rubin allows to view the social process of production seen as a whole (the social relations of production), the gnoseology of capitalism must allow us to necessary abstract and "separate" the social forms that human relations adopt in capitalism, including its technicalmaterial process of production, and this process as itself. And is in this technical-material process of production where became the matter-form-truth gnoseological relation. Where the blood pumping of the capitalist economic system is developed. Because the blood pumping of capitalism is the production of goods, as Marx makes it clear at the beginning of the Volume I of The Capital. Goods are the social, historical, technological and concrete form which adopts the matter on which objectively operations are made, and the associated values with the goods (the use value, objective and historical, and the value), are the gnoseological truth derived from relations between matter and form. This is the gnoseological basis of TLV. Let's see how Rubin explains it.

There is a connection an a close correspondence between the process of production of material goods and the social form in which it carries out, i.e., the whole of the relations of production among men, which is regulated by a particular condition of the productive forces, that it to say, the material process of production. The given system of the relations of production, in a certain sense, is a closing entity, headed by a willingness and adapted to the material process of production as a whole. Obviously, changes in the material process of production can cause inevitable changes in the relations of production. But these changes are made within these relations and are carried out by its own internal forces, by a decision of its administrative agencies. The changes are caused by changes in the production process. The unity that exists at the beginning allows a correspondence between the technical-material process of production and the relations of production which make it up. Later, each of these elements is developed on the basis of a previously given plan (we could say that the closing is equivalent to the planning and planning the closing). Each element has its own internal logic but, because of the initial unity, does not provide any contradiction between them. 
The relations of production do not exist in advance, but it was established through the transfer of things from one subject to another. For this reason the character of it is social (material). The objects are passed on from one subject to another not by relations in advance, but of buying and selling, commercial, limited to the transfer of these objects. The transfer of things has a technical (and social) significance. Things are goods in the economic field.

In a market society, from the point of view of the technical process of production, each product of labor must proceed from one stage of production to another, from one production unit to another, until it receives its final form and passes from the production unit of final producer or intermediate trader to the economic unity of the consumer. But given the autonomy and independence of the separated economic units, the transfer of the product of an individual economic unit to another is possible only through the purchase and sale of the agreement between two economic units, which means that it establishes between them a relation of particular production: purchase and sale. The relation of production among certain people is established at the time of transfer, and after the transfer is interrupted again. In the process of exchange was inextricably bound up with the relations between the people and the movement of goods in the production process (the technological and the social, the basis and the superstructure).

The personification of things (another commodity fetishism characteristic) allows its holders to appear and participate in a particular form of relation -class relation-, in specific relations of production with other people. Marx considered social production as a continuous dialectical recurrent process of reproduction in which each link is the result of the previous link and the cause of the next (recurrent rotation is the idea that, for Gustavo Bueno, is definitely associated with economic Reason, from the coordinates of TCC). The social form of things (the goods) is at the same time the result of the previous process of production and of expectations about the future.

When the participants in the act of exchange compared the products of their labor with a third product, this role is that of money in embryonic form, because it is not money before or after the act of exchange. Money is a key institution in any complex economic system. Without money, there is no bodily translating of value measurable objectively. And value, as the truth of the gnoseology of capitalism, is inseparable in many ways of money. And value (like money), associated with goods, is also a thing. And the process for producing this thing also has a social, historical, technological and concrete form.

The thing -the good, and the value (the prices)-, through which people fall into defined relations with each other, plays the role of "intermediary" or "carrier" of the relation of given output. In addition to there being material or technically as a concrete consumption good or a mean of production, the good seems to acquire a social or functional existence, i.e., a particular social character through which expresses the relations of production given, giving the particular things a social particular form. In fact, the value is only in itself a material expression of a relation between the productive activities of men. The value, as a relation of production, is represented in one good, and a good "represents" a relation of production. Relations of productions are social forms of manipulation of matter in the economic field, and values are its gnoseological truth, but all 
are, at the same time, relations of production. The economic categories are nothing more than theoretical expressions, "abstractions" of relations of production (offer and demand are relations of a certain production, like individual exchanges). The form of goods reflects the properties of the social area (of the economic field, in a historical and technological meaning).

The material existence of the goods is not opposed to their social existence, because the second presupposes the first, and both are equally materials. The social existence, as material existence of all things produced, is guaranteed by the circulation of the same, through the capitalized value in money, the value of the cost of production, the price of production, the market price and all the intermediaries between cost of production and market price, and the use value, institutionally and technically categorized through institutions as the World Customs Organization (developers of the Harmonized Commodity Description and Coding System, a technical procedure for objective classification of use values of the goods on a universal level).

The material existence of the goods, in addition, is due to the technical functions of the same, because the technological aspect is also applied to the economic field, even from "outside" of the same (by influence), and therefore the labor activity is conditioned by both, which are combined to barely be distinguished.

In his final analysis, Marx notes that there is a technical-material production process, and what he does is to take an interest in the economic form and the social-historical determination form which adopts the technical-material production process. That is to say, Marx followed a categorial closing method: matter-form-truth. He noted a given matter, he wondered about the way that matter takes a form (a social, historical, technological and even political form), and determines (or try to determine) a truth, product of a social form that acquires the matter. Even, value (gnoseological truth) affects social relations of production, between autonomous producers of goods, with its value fluctuations depending on changes in the technical - material process of production and its influence in labor distribution of political societies (even when State imposes taxes to business companies, enterprises and other bourgeois institutions, getting an essential part of the value produced).

So the starting point of TLV is a specific social milieu, a political society with a certain productive structure. In a market capitalist economy, labor relations of production between men, necessarily procure the form of the value of things, and can only appear in the material form; the labor (the work on the economic field) can be expressed only in terms of value. Here the starting point of the research is labor, as operations of subjects. Value is:

a) A social relation between people.

b) Assume material form (goods, money, prices, etc.).

c) Relates to the production process.

Market price is not proportional to the value of the good. The necessary amount of labor for the production of a good is proportional to the so-called "price of production" (or producer price), which is equal to the cost of production plus the average profit on the capital invest. The value represents the average level around which fluctuate market prices and with which the prices would coincide if 
the social work is proportionally distributed between various branches of production. As well it would establish a state of balance between the different branches of production. The value of the goods is directly proportional to the amount of work needed for its production. The exchange of two different goods according to their values corresponds to the state of balance between two branches of production. The work that creates value not only appears as work quantitatively distributed but also as work socially matched (or equal), that is to say, as "social" work, understood as the total mass of equal and uniform work of society. The work (labor) has these social characteristics not only in a market economy, but also in a socialist economy, and this is essential to understanding the gnoseological truth of TLV.

The amount of socially necessary labor for the production of one unit of a product, which determines the value, depends in turn on the productivity of labor. The driving force that transforms the entire system of value originates in the technical-material process of production. The value plays the role of regulator, and TLV is the "law of balance" of Political Economy. The TLV analyses laws of exchange, the laws of equalization of goods on the market, only if these laws relate to the laws of production and distribution of labor in the market economy. The value, as a product of labor, permits an alignment of goods, the equalization of several concrete forms of labor as a component of the "total" social labor, distributed in several branches.

In conclusion, the value is a relation of production among people that takes the form of a property of the goods. A concrete historical form, like any other commodity, which can only exist in a certain determinant context, that arises from the institutionalized operations of subjects on the matter of the Nature and/or other regions of the economic field, establishing relations such that give rise to a final value that give expression to, and also regulates, as the heart pumping blood circulation, the whole social process of production.

\section{2.b.5. Value as a synthetic identity: the technological closing of TLV}

To finish closing the gnoseology of capitalism of Marx-Rubin, and from the coordinates of TCC, we lack to refer to the value as a synthetic identity. Now we explain schematically what is a synthetic identity. It is not here to talk about the idea of identity in a extensive manner, because it goes beyond the claims of this short essay. Only we will deal with the idea of identity in a gnoseological sense, and in relation with the TLV.

To define the concept of truth by means of the synthetic identity (once we alleged the definition of truth by the identity) it may be seen redundant if it is that every identity is synthetic. However, it is not; because even when the idea of truth wrap to the idea of synthetic identity, mutual cannot be maintained: it cannot be said that all synthetic identity constitutes a gnoseological truth. This is because there are various types of synthetic identities; we will just go to refer here the more generally types that we call synthetic identities: synthetic schematic identities (or identity schemes) and synthetic systematic identities. The schematic identities can also be called "configurations" or configurational identities, and really are results of operations. The systematic identities are relations, and could be called "propositional identities", in response to its ordinary way of expression. The scientific truth is associated with the systematic 
identities, and not with the schematic identities (although not for this reason it may be considered to be independent of them). In both cases, systematic and schematic synthetic identities, are involved operations that take place between various terms "synthetically" compounded.

The constructive processes reach their scientific status when it determines a proposition which expresses a relation of synthetic identity. However, it cannot be said that all synthetic identity constitutes a scientific truth, because of the various types of synthetic identities. The idea of synthetic identity is taken from the Mathematics. The operation $7+5=12$ shows a categorial closing in Mathematics, being 12 a systematic synthetic identity, because it is transcendental to the terms 7 and 5 by the ratio + support. The intertwining of schemes of identity gives rise to determinant contexts, prior to the formation of synthetic identities. In our mathematician example, the determinant closing field is the field of natural numbers in Mathematics, and the closing occurs because 12 is a natural number related to other natural numbers, 7 and 5 , by a sum operation.

In the case of the value we find a scheme of identity (a synthetic schematic identity), because the value is the product of operations on the technicalmaterial economic and productive field (on the economic field). Then we do not have a scientific truth in an alpha-1 gnoseological state. But because the value is a cultural product produced by workers in the economic field, which is "segregated" of their operations once they have finished to produce it -and it allow them to continue to produce value(s)- which is also a product of operations for putting together/separate values (goods) that are shaping the final good until completing the cost of production, and because it has an enormous influence over the will of those who have produced it, in addition of a social influence that we have already pointed out, the degree of gnoseological truth is considerable, greater than that of the Theory of Marginal Utility, which do not come from operations. While the marginal utility is, in spite of its mathematical (idiografic) construct, an extraeconomic idea, value is a economical-technological concept. Then there is a technological closing of schematic synthetic identity that reaches a gnoseological degree of II-alpha-2 (Marginal Utility, as a concession, cannot overcome the beta-operative state). Degree which, incidentally, reaching the whole classical Political Economy, including Marx and, of course, Rubin.

\section{3.- Conclusion}

In this brief essay we have wanted to show how the legacy of Rubin overflows the boundaries of the field of Political Economy in that he was moving, and in the same manner in which Marx overflowed the same economic field. We have shown how Rubin, in our opinion, is the best interpreter of Marxist's TLV, getting his Essays... at the height of The Capital as a clarifying essential work about capitalist reality.

For us, that takes the work of Isaak Illich Rubin as referred to in our PhD. Investigation (now in drafting process), Essays on Marxist Theory of Value is, as we said at the start, first and foremost, an ontology and a gnoseology of 
capitalism, like the Political Economy works of Karl Marx. And say this is to pay Rubin, as well, the best tribute that we can offer to him.

\section{Bibliography}

Santiago Armesilla:

- Valor, trabajo, demanda y Estado: esbozo de una teoría circularistasintética del valor-trabajo, Revista El Catoblepas, nº 98, abril 2010, p. 16.

- $\quad$ Análisis comparativo de la teoría del valor-trabajo y de la teoría de la utilidad marginal desde la teoría del cierre categorial, PhD. Dissertation, not published, june, Madrid 2010.

Gustavo Bueno:

- $\quad$ El papel de la Filosofía en el conjunto del Saber, Editorial Ciencia Nueva, Madrid 1970.

- Ensayo sobre las categorías de la Economía Política, La Gaya Ciencia, Barcelona 1972.

- $\quad$ Ensayos Materialistas, Taurus, Madrid 1972.

- $\quad$ Teoría del Cierre Categorial, Tomos 1-5, Pentalfa, Oviedo 1992-1993.

Javier Delgado Palomar:

- Sobre la necesidad del estudio filosófico de la Economía Política, Revista El Catoblepas, n² 2, abril 2002, p. 2.

- La Economía como disciplina científica, Revista El Catoblepas, n 13, marzo 2003, p. 13.

Pelayo García Sierra:

- Diccionario Filosófico, Biblioteca Filosofía en Español, Oviedo 2000.

Carlos Marx:

- $\quad$ El Capital, FCE, Ciudad de México 2001.

- Elementos fundamentales para una crítica de la Economía Política, Siglo XXI Editores, Buenos Aires 2010. 
Isaac Illich Rubin:

- Ensayos sobre la teoría marxista en español, Cuadernos de Pasado y Presente, Buenos Aires 1974.

- Historia del Pensamiento Económico. Tomo 1, los mercantilistas, Maia Ediciones, Madrid 2011.

Joseph Alois Schumpeter:

- $\quad$ Historia del Análisis Económico, Ariel Ediciones, Madrid 1994. 